\title{
Re-Inventing Public Housing
}

FREDERICK BIEHLE

Pratt Institute
In Public Housing that Worked Nicholas Bloom championed the success of the New York City Housing Authority, but to do so had to champion bureaucratic workability over architectural value. In fact, his assessment had to disregard the fact that nearly all of the high-rise low-income housing projects are psychologically partitioned island wastelands, anticities within the city.

Louis Wirth, Jane Jacobs and now Steven Johnson have offered their generational testaments to density, diversity, mixed use, and continuity- what they considered made urban life meaningful. Steven Conn summarized- "the problem of the 21st century will be how we re-urbanize, how we fix the mistakes of our anti-urban 20th century."

The Pratt Institute UG urban design studio, Re-inventing Public Housing, is intended as one step toward meeting the challenge starting with the question- must we really accept the super block public housing estate for what it is or is there a way to transform and reinterpret it, and by doing so eliminate its stigma, its isolation, and anti-urban grip on the city?

\section{INTRODUCTION}

In his 2008 publication Public Housing that Worked Nicholas Bloom offered an in-depth critique of low-income high-rise public housing in the United States that surprisingly overturned the conventional wisdom that has held it to be a failure. ${ }^{1} \mathrm{His}$ thesis was that while most of America's superblock public housing was, in fact, a disaster, New York City's was not. New York City was different. This was the city whose Housing Authority (NYCHA) had created, overseen, and maintained a product of twenty-six hundred buildings and a system that could, and continues to, satisfy the housing needs for over 400,000 tenants. In short, it worked.

To stake this claim, however, Bloom had to redefine the frame through which affordable housing would be evaluated. His new position promoted bureaucratic workability over any issues related to its physical reality, its architecture. He readily acknowledged this. To get to his conclusion he had to defend several specific architectural assumptions that had been institutionalized by Robert Moses and NYCHA:

1. That "slum" clearance was always a net positive.

Most NYCHA projects were not built on vacant land, and were thus only possible by the demolition of multiple block neighborhoods, often occupied by tenement block housing. Eliminating these neighborhoods seems to have been an equally strategic goal to greenlighting a project as more than just housing advocates were interested in "slum" clearance. Because the replacement system that was already institutionalized by 1940 to replace the neighborhoods would be based on the superblock housing estate model demolition inevitably ended up removing the baby with the bath water. Clearance removed old tenement houses-yes, something which could be seen as a net positive from a health and safety perspective, but it also removed the street, the public realm in which the collective activity of the neighborhood took place. While a physical replacement for the tenement house apartment would be provided, an appropriate public space to replace the now absent street would not.

2. That the formula for a superblock housing estate that would a) aggressively and intentionally turn away from the fabric of the city that surrounds it, and b) zone its use to be exclusively residential and thereby eliminate any sense of urban continuity with its surrounding mixed use context was an acceptable, rational, even positive idea. (see Fig. 1)

3. That the decision to construct a kind of housing that was intended to look poor by virtue of its meager budgeting, absent of any sense of architectural detail or identity was also acceptable.

4. That not shaping the residual space opened up by the smaller lot coverages due to taller buildings was also acceptable, thus elevating abstract aesthetics over social concern.

In short, Bloom tells us that we should accept NYCHA's public housing 'project' for what it is- 2600 buildings on 154 sites and over 400,000 tenants all living with "well maintained brick buildings, mature plane 

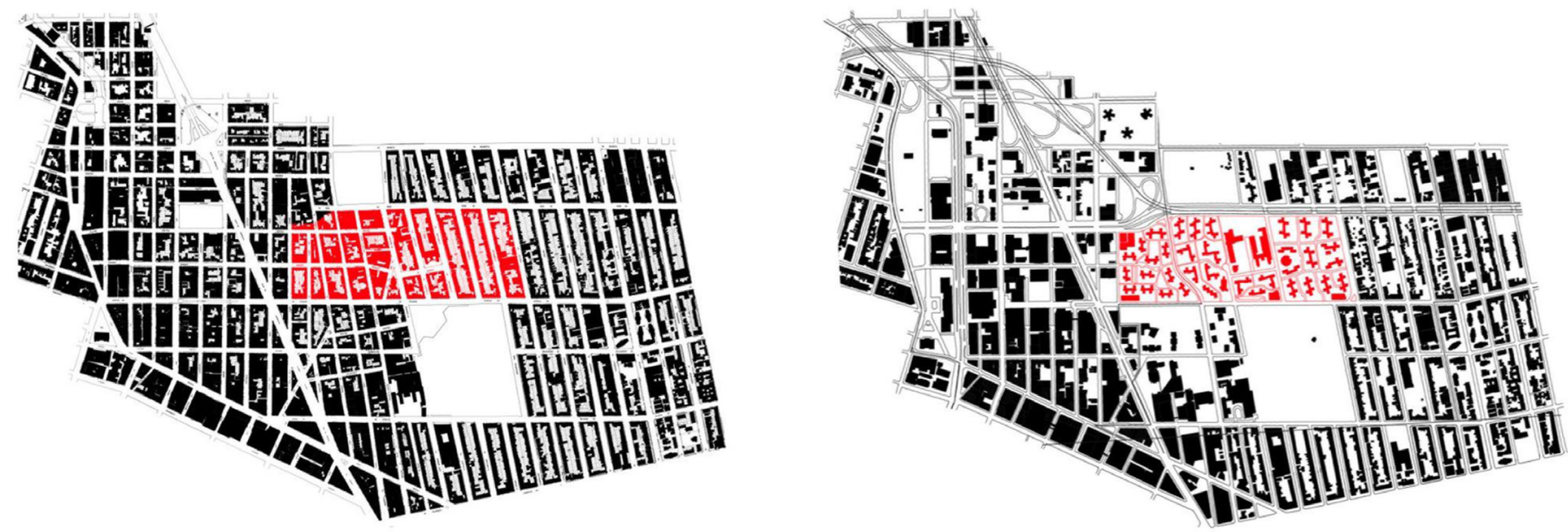

Figure 1: Ingersol/Whitman superblock in Brooklyn before and after slum clearance showing the removal of the street and disorientation of the completed project from surrounding blocks.

trees and green lawns... (all of which) have made NYC public high-rise housing a smashing success." ${ }^{2}$ As positive as these observations may be, they still disregard the architectural facts that are sending a very much contradictory message- that the projects are a psychologically partitioned (both physically by its stigmatized second ghetto appearance and spatially by its withdrawal from any larger idea for the public realm) series of island wastelands, anti-cities within the city. ${ }^{3}$

\section{WHAT MAKES URBAN URBAN?}

Certainly "a decent home and suitable living environment" (the stated goal of the original 1949 federal housing act legislation, allowing for the use of eminent domain to clear urban slums and replace them with new housing) is important, but it is remarkable how antagonistic, even cavalier, housing advocates and planning authorities were to the city's underlying 19th century fabric. The spatial balance of the urban gridiron between street/sidewalk and building fabric has given each city its own unique characteristics while also providing a more general framework for urban life as it has evolved over at least two millennia. Yet between 1932 and 1960 very few architects or urban planners seemed remotely cognizant of this. The crisis of decentralization, relieving urban density and overcrowding, had become an at-all-costs agenda for them.

One exception was the Chicago sociologist Louis Wirth, who in 1938 tried to give a more precise definition for urbanism by noting that it certainly "included size, density and heterogeneity" but also that urbanism as a way of life meant something different, experiencing a set of human interactions that were impersonal, rather than intimate. ${ }^{4}$ This is the something Jane Jacobs magically described in her Life and Death of American Cities as "the daily ballet" of the sidewalk. She was referring to the episodic and anonymous interactions which make up each persons "informal public life", the world of mediation that operates between the more personally determined public and private lives. The informal public life, then, is urbanism as lived and experienced, the unplanned participatory theater of the street and sidewalk. ${ }^{5}$
Steven Johnson, in his 2001 publication Emergence: The Connected Lives of Ants, Brains, Cities and Software cites Jacobs specifically for her description of the dance of urban life. For him, she is like the boy in the Hans Christian Anderson tale the Emperor's New Clothes calling out the planners naked ignorance in not comprehending, even at the most basic level, what really makes cities work. It was density, diversity, mixed use, and continuity she insisted. Johnson continues by saying that the city is, and always has been, more of an emergent than authoritarian system, evolving and operating bottom up as a constantly mutating multitude of independent interactions. He concludes by identifying the value that such a system can offer saying "better sidewalks make better cities, which in turn improve the lives of the city dwellers...city life depends on the odd interaction between strangers that can change one's individual behavior ... encountering diversity does nothing for the global system of the city unless the encounter has a chance of altering (one's perspective)". ${ }^{6}$

In another remarkable book Americans against the City, Steven Conn traces a consistent and repetitive attack on the city throughout the 20th century. By declaring the architects, city and regional planners, policy makers, politicians, federal housing administrators, decentralists, social engineers, garden city advocates, folklore enthusiasts, and academic intellectuals to be ANTI-URBAN he opens up a space to actually celebrate the qualitative values of an urban life, to articulate a vision of positive urbanism. He quotes William Whyte, an editor at Fortune magazine, saying of urban renewal "most of the rebuilding under way was being designed by people who actually don't like cities. They do not merely dislike the noise and the dirt and the congestion, they dislike the city's variety and concentration, its tension, its hustle, and bustle. What made the city so good, was all the things the planners wanted to eliminate."

So, as certain perceptions today have changed and we can argue along with Whyte for what makes the city good, it still remains unclear just what we can do about the vast urban planned legacy, in New York City, those 154 sites. Conn laid down the challenge in his concluding 

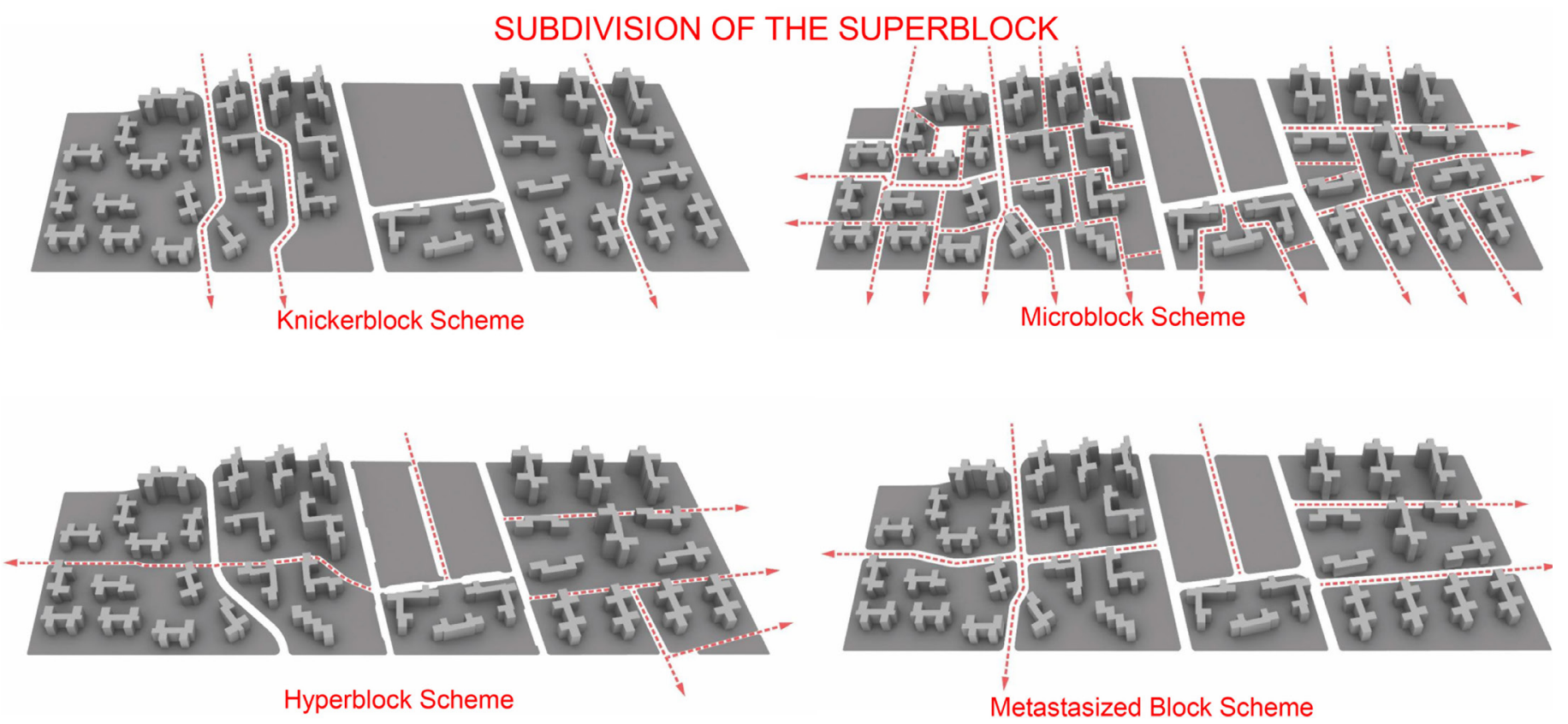

Figure 2: Four Schemes with different strategies for subdividing the superblock to introduce new streets

sentence- "the problem of the 21st century will be how we re-urbanize, that is, how we fix the mistakes of our anti-urban 20th century." ${ }^{8}$ It will be no small undertaking.

\section{THE OPPORTUNITIES OF THE PRESENT}

Fifty years after the construction of the last major NYCHA sponsored public housing project, New York City no longer has the money to maintain them. Four recent events have coincided to alter the laissez-faire perception of NYCHA's public housing estates and create what may be a truly honest opportunity for change:

1. We have seen a progressive and steady decline in the crime rate. Beginning even before the Rudolf Giuliani administration and continuing under Michael Bloomberg, the city has experienced 25 consecutive years of decreasing crime and thus a reciprocal reinvigoration of the life of the city street to go along with it. This is particularly critical in more recent years where the urban contexts around public housing estates have normalized. (In an interesting potential feedback loop, the revitalizing of city streets may be a significant contributor to the continued statistical drop in crime that has continued under current Mayor Bill de Blasio, even with the taking down of the controversial stop and frisk program).

2. The remarkable building boom that started in the mid-1990s, fueled in particular by rezoning has run out of space on which to build. It is now perfectly acceptable to build high rise luxury housing or midrise market rate housing directly adjacent to public housing estates without the fear of risking property values, something not even imaginable ten years ago.

3. The first foray into the idea of exploiting the excess FAR present in the housing estates for market rate housing. An RFP (Request for Proposal) issued in Mayor Bloomberg's final year called for developers to utilize excess open space in a series of public housing estates so as to create new for-market (80-20) luxury tower projects. The carrot with this proposal was that income from the new housing would help pay ongoing maintenance and upkeep costs for the housing estates. Most public housing was constructed with a 50-year lifespan. By 2018 every project will have expired and be in need of serious restoration. While the RFP has been taken down by Mayor Bill deBlasio in part due to public outcry, he has not entirely taken this idea off the table. Finding a way for private development to fund the financial needs of low income housing is simply too attractive.

4. After 12 years of a city administration that was pro private development the new mayor has made it a part of his mandate to reengage the idea of public housing. With his Five Borough, Ten Year Plan, Housing New York, deBlasio intends to foster diverse livable neighborhoods, preserve the existing housing stock and build new affordable housing, ultimately creating 200,000 new units.

The past two years, Pratt Institute UG Architecture department offered an urban design studio intended as one step toward meeting Steven Conn and Bill de Blasio's challenges. We started with the questionmust we really accept the super block public housing estate for what it is? Or is there a way to transform and reinterpret- essentially contextualize it- and by doing so eliminate its stigma, its isolation, and its anti-urban grip on the city?

It has been quite some time since public housing carried the flag of the future by replacing what was then a discredited prior housing model, the tenement house, condemning it as a slum and destroying it to make way for what it assumed was a brave new world. But perhaps its time has come again. As the superblock public housing estate has itself been universally discredited as fundamentally anti-urban, can we identify a way and a means to transform it, only this time without the wrecking ball. 

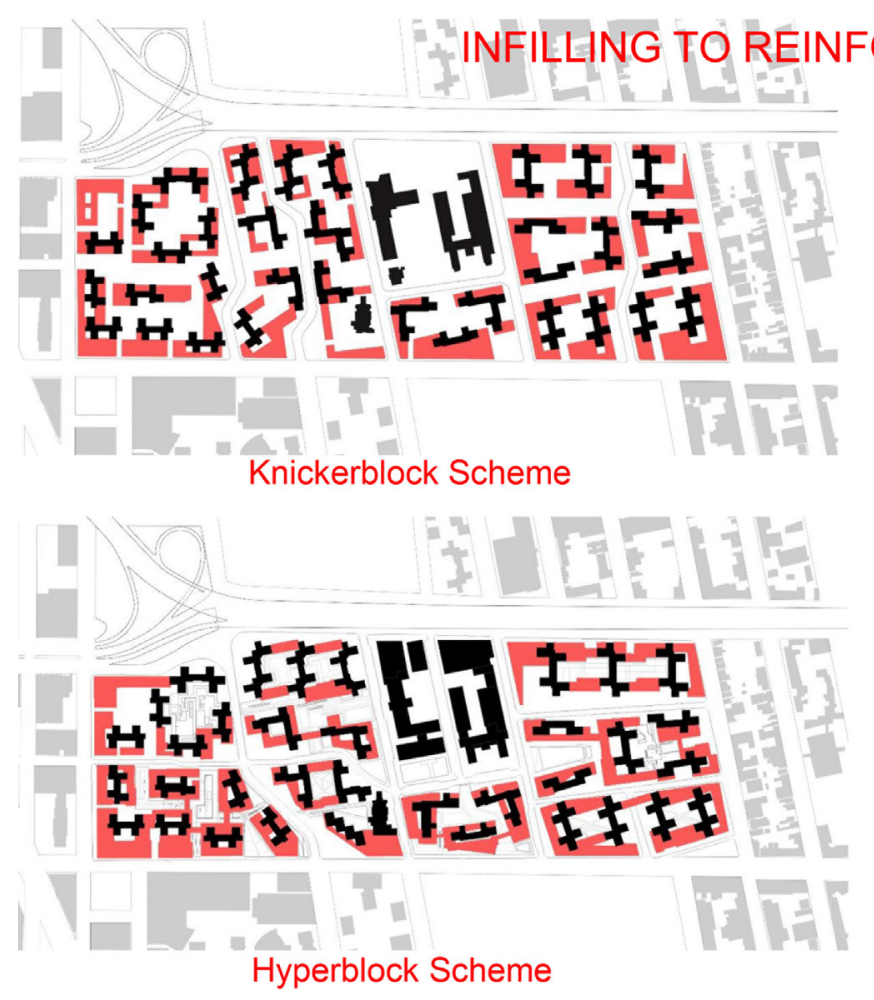
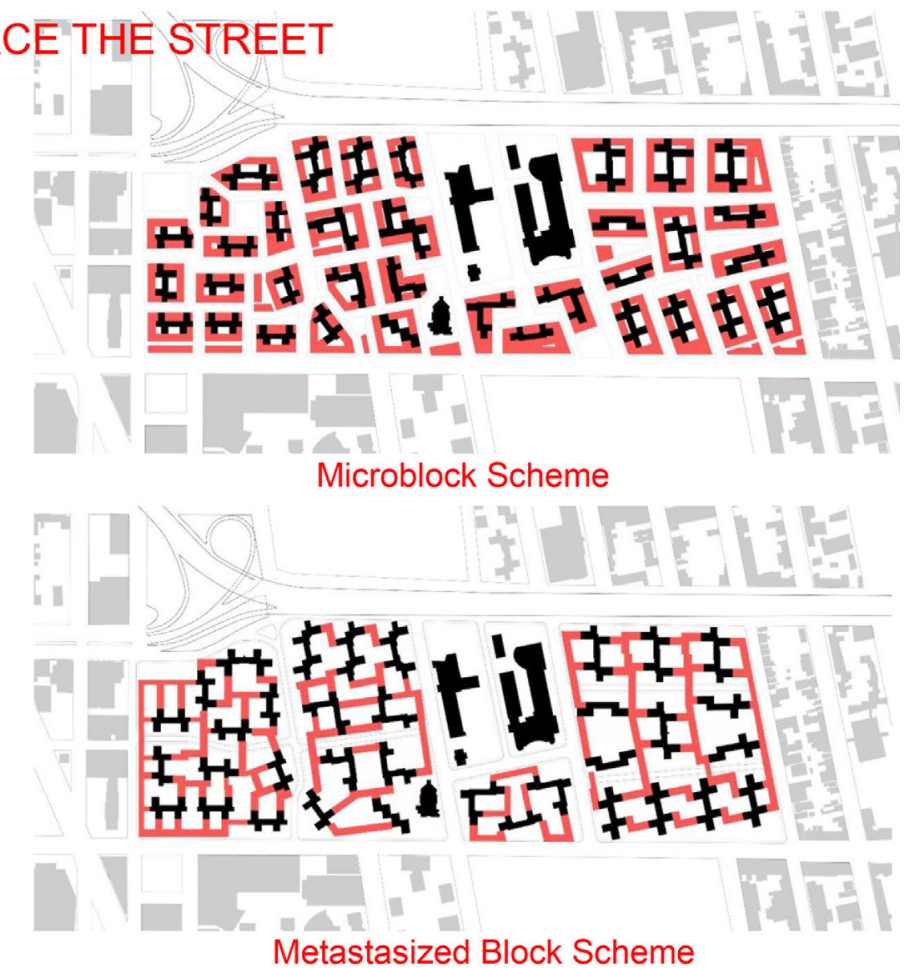

Figure 3: Four schemes with different strategies for infilling to define new streets and perimeter block courtyards

The site used for the project was the Ingersol/Whitman (originally Fort Green) Housing Projects in Fort Green, Brooklyn (see Fig. 1). It sits along Myrtle Avenue facing Fort Green Park just a stone's throw from the Navy Yard. When it was built in 1941-44 it was the largest public housing development in the country. Twenty-two original urban blocks were demolished and converted into five landscaped superblocks holding 35 hudson river red brick buildings ranging from six to 15 stories with 3500 apartments.

The longer history of the Ingersol/Whitman Houses closely adheres to the three periods identified by Bloom that have come to define public housing in New York City. It was constructed and received its first tenants during NYCHA's initial phase of building (1934-1968). During this period, the Housing Authority was an institution dedicated to the idea of model housing as a municipal service. In spite of what might seem to be conceptual design flaws, the authority became a production machine, replacing designated areas with well- built, tightly managed housing estates. The spanking new housing was occupied by a working class population that had to meet a rigorous set of qualifying standards, including proof of a steady job and reputable character.

Following WWII production at the Navy yard (where most Ingersol/ Whitman residents worked) declined significantly and many of the original inhabitants either moved on or fell on hard times. In 19571958 the houses were renovated and divided into the Walt Whitman Houses and the Raymond V. Ingersoll Houses to facilitate managerial oversight. Within another year the project was profiled as a stark example of public housing's failure with broken windows, cracked walls, inoperative lighting, and elevators being used as toilets. It would remain in this condition as NYCHA entered its second and most problematic phase, changing its mandate to become a form of welfare state public housing. The surrounding Fort Green area became further depressed by the decommissioning of the Navy Yard in 1966 and the dismantling of the Myrtle Avenue elevated train in 1969 which made the area much less attractive to Manhattan commuters.

The third phase began in the 1990s and runs through to the present where NYCHA has attempted to engineer a return to a vision of public housing as affordable housing so as to serve the city's working poor, in particular families.

The Whitman/Ingersol houses today contains an undercurrent of this dark history, standing out from a gentrifying surrounding neighborhood that has become quite recognizable to the larger world. Luxury highrise developments jostle for position along the nearby Flatbush Avenue corridor and all of the open lots along Myrtle Avenue, parking lots since the late 1960 s are scheduled for infill market rate housing.

\section{POSSIBLE SOLUTIONS}

Included are four proposals to re-invent the public housing site of the Ingersol/Whitman houses. Each is to some degree a variation on the perimeter block housing type. The studio generated other strategies but these four present a more coherent comparative taxonomy.

Each project had to address three fundamental issues:

First - Restoring the idea of the street. The superblock had eliminated not only the actual streets of Brooklyn's historic gridiron, but the very idea of the street- as something that is present in section 

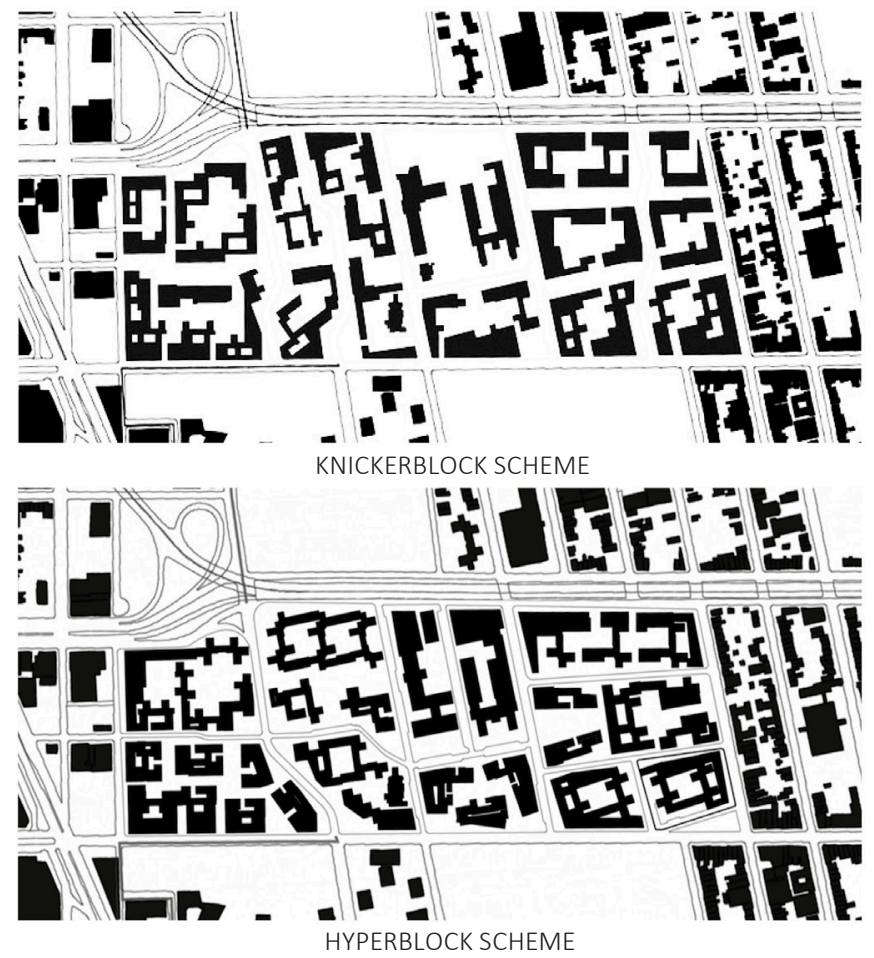

Figure 4: Figure Ground drawings of the four schemes

spatially, where the collective activity of the neighborhood takes place. Subdividing the superblock again into smaller pieces so as to introduce a more porous vehicular and pedestrian circulation system was everyone's first step (see Fig. 2).

Second - Reshaping the urban fabric in relationship to the altered street pattern. A new lower scale infill architecture had to be introduced to the site so as to shape the form of the open space specifically, as private courtyard, as public room and as definer of the street (see Fig. 3).

The existing tower cores could then be integrated into this new urban pattern. The result is a new urbanized figure-ground plan into which the footprint of the towers disappears. It is this re-shaping of the street level architecture that allows the recovery of urban continuity with the surrounding context. The existing towers maintain their "access to light, air, and health", but the architecture of the street reintroduces the urbanism that has been absent- retail shops, restaurants and cafes, small business opportunities, community facilities, etc.

Third - Delineating the newly defined territories of public space, semi-public space, and private space. When the superblock took away the street, it also removed any conventional understanding of the separation between public and private realms. Re-integration with the fabric reestablishes the more familiar clues of spatial usage.

The buildings appearance is also a part of this issue. All existing buildings were to be reskinned, allowing for the challenge of a modest palette of materials being ordered so as to provide difference and variation rather than sameness.
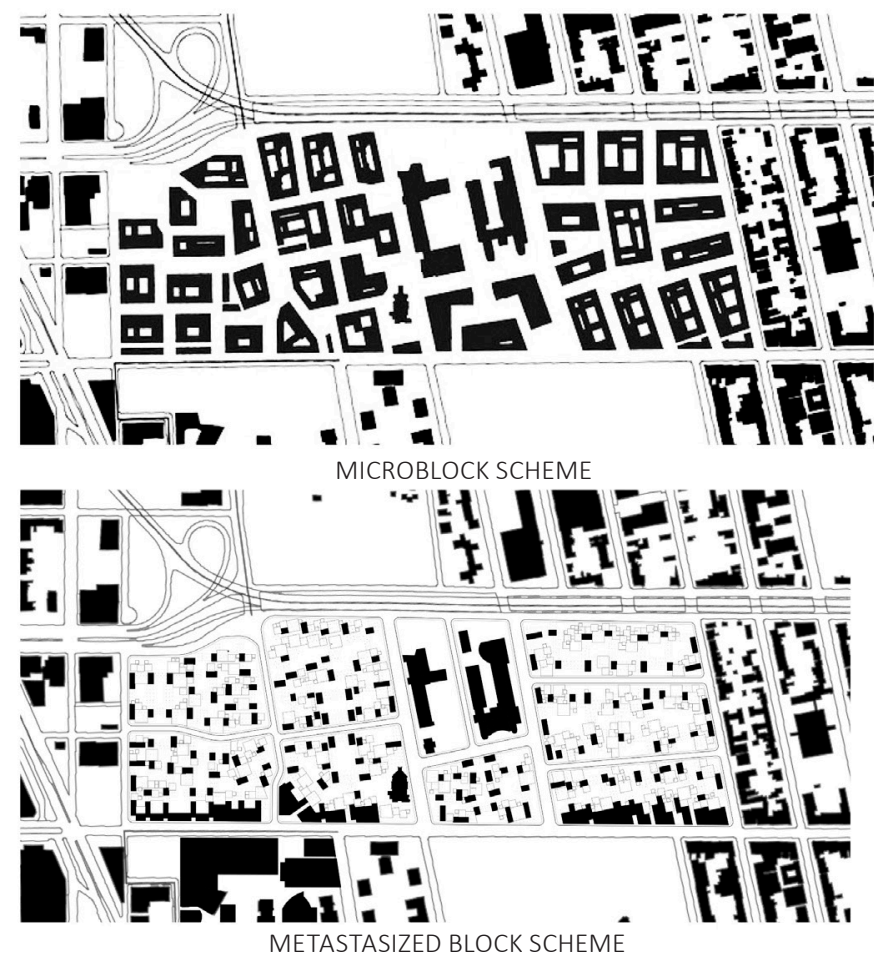

With these three prioritized issues, these are the proposals in greater detail (see Fig. 4):

The Knicker-block scheme, by Peter Kim and Han Kim (named after Manhattan's Knickerbocker perimeter block Housing of 1934) is perhaps the most articulate of the solutions. It takes the existing low income residential towers and clusters them into more comprehensible units of between two and six buildings. The super block was broken up by three new meandering streets running north and south while a prioritized green pedestrian promenade runs through the site east and west linking the neighborhood more coherently to the existing institutions (school, library, church and hospital). The clustering is achieved by adding a two story base or apron that connects the existing towers together offering street front commercial space for the general public and semi-private interior courtyards for the residents.

The Hyperblock scheme, by Javier Marcano and Veronika Suarez, is similar, different in its choices of clustering and in its interpretation of the courtyard as something public rather than private. Conceptually a repeating block pattern with an open center (as in the historic plan of Savannah, Georgia) each space was ultimately shaped and configured by the demands imposed by the tower footprints, the newly proposed programs, and a larger sense of episodic interconnectedness.

It clustered the existing towers together into consciously different types of blocks shaped around public or semi-public interior courtyards. The public courtyards help to reinforce different identities for different locations. These courtyards are intended to carry 


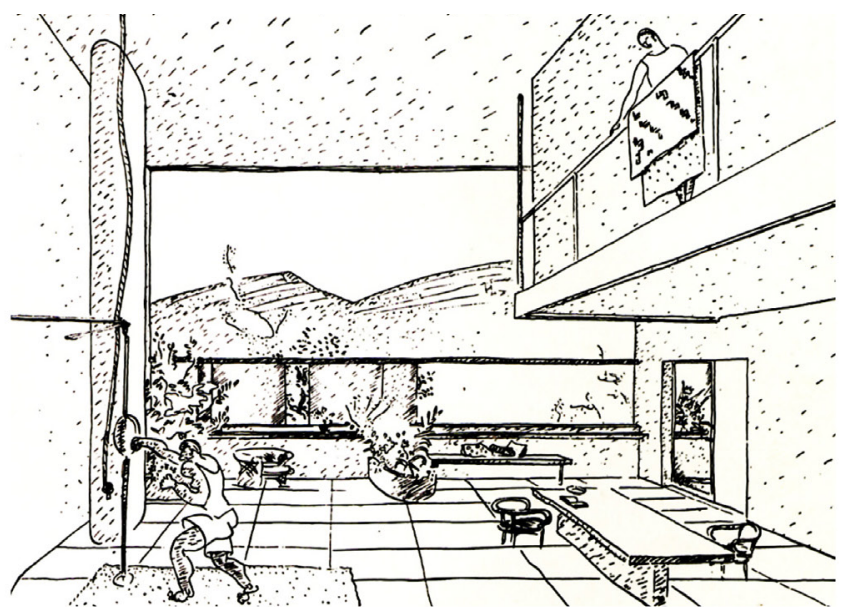

Figure 5: Visions for the future of Public Housing- Le Corbusier's anti-city within the city and Re-invented Public Housing

the same vitality as the street. Some are a landscaped extension of community centers for residents only, others support the larger institutional programs such as the public school, the library or a newly designed museum.

Redefining the street and public courtyard by adding shared uses is intended to cultivate a public trust in the site and foster a healthy community for what will no longer be able to be called a superblock.

The Microblock scheme, by Hillary Flannery and Kaifang Zhang, pushes the perimeter block idea to excess by allowing each existing building to determine its own individual block. Each existing tower is provided with a new base two to three stories in height that becomes the basis of an individual block. The pre-existing minimal architectural footprint is entirely reversed, with the new forms filling each block site completely to generate an intentionally dense urbanism. That density is aerated, however, by the consistent inclusion of smaller internal courtyards, around which a variety of programs are distributed- institutional, retail/commercial, and community.

As an urban pattern it generates an irregular agitated grid that allows missing pieces to become figured neighborhood gardens. The streets that thread through vary in width and hierarchical importance. While the superblock has now been divided into a fully porous street pattern, the repeating absence of through access makes it function as a safer, primarily residential neighborhood.

The housing block as freestanding mark in an open landscape is the underlying premise for nearly all of NYCHA's 154 projects including this one, the Ingersol/Whitman houses. For the final Metastasized block scheme, by Michael Rosen and Yuli Huang, those marks are allowed to grow and ultimately metastasize by extension and continuation of its existing fabric, closing in on itself to create a new organic form, a vast honeycomb of what appear to be courtyard oriented spaces. The character of the site shifts from objects in a field to a maze of interior spaces.

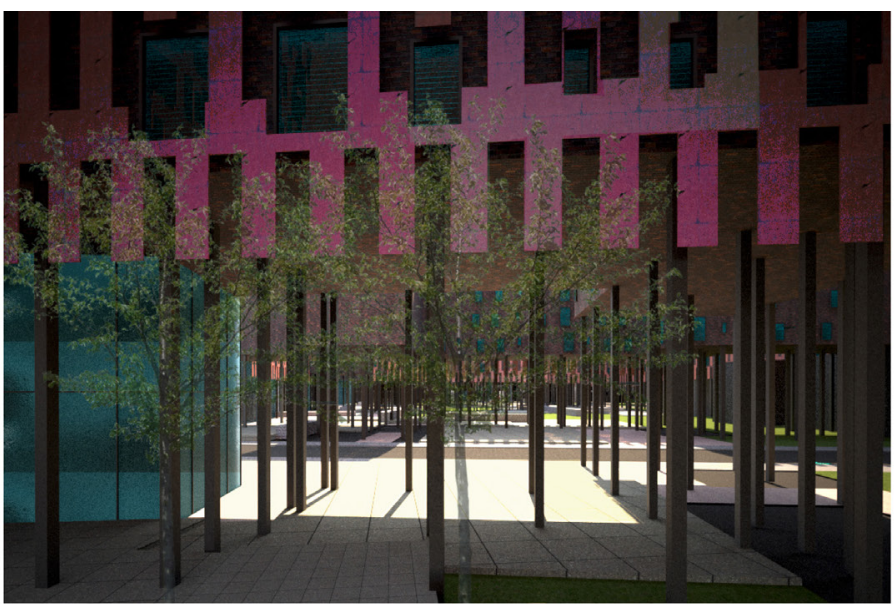

The additions would propose to integrate and distribute middle income and even market rate housing into the overall complex generating an extreme density of mixed incomes without resorting to the high rise tower. The potential claustrophobia generated by the excess of enclosed spaces is resolved by stripping out all ground floor and second floor architecture, creating a transparent, piloti-supported, horizontal realm.

New entrances are glass pavilions so as not to disrupt the spatial continuity. Semi-private and semi-public use is integrated by breaking up the larger landscape into paths, outdoor seating and bounded passive and active recreation. The transparent semi-public world is buffered from the immediate context by a collar of single story commercial space.

What sets this particular project apart is that it seeks to propose a new variation on a very old idea. Historical precedent would suggest that all cities gain identity by the degree to which they can integrate interiority and density together with porosity. The result in this case is in the extreme nature of both, a kind of ecstatic interconnectedness.

America's political and social polarization today has been described as being a direct reflection of its physical and architectural polarization, itself the cumulative result of the 20th century's anti-urban positioning. That sensibility appears to be changing, almost instantly. The present generation doesn't want to own a car. They want the positive vitality of urban life and nothing more. The right side of the future is not about continuing with a culture of selective homogeneity, it is about dismantling it, and the form of the city is rising and filling in to accommodate this. (see Fig. 5)

Urban renewal in America, which has left us with hundreds of super block housing estates, should not be looked at a failure to be erased (as is being done in Chicago, Baltimore and New Orleans) but as something unfinished. These remarkable undergraduate proposals offer not so much single solutions for a single unique site as instead tactical prototypes, templates capable of being applied to other sites and other cities everywhere. 


\section{ENDNOTES}

1. Nicholas Bloom, Public Housing that Worked, New York in the 20th Century (Philadelphia: University of PA Press, 2009) as made explicit by his title. He has since published a new survey of public housing in NYC, Affordable Housing in New York.

2. Bloom, Public Housing that Worked, New York in the 20th Century, p. 2

3. As a comment on this I personally have lived in New York City for 35 years and until I began work on the research for this studio had never knowingly walked into and through a public housing estate.

4. Steven Conn, Americans against the City: Anti-Urbanism in the 20thCentury (New York: Oxford University Press, 2014) p. 306

5. Jane Jacobs, Death and Life of Great American Cities (New York: Random House, 1961) p. 57but chapter 3 in particular, The Uses of Sidewalks: Contact.

6. Steven Johnson, Emergence: The Connected Lives of Ants, Brains, Cities and Software (New York: Scribner 2001) p. 94-97

7. Conn, Americans against the City, p.189

8. Conn, Americans against the City, p. 306 